\title{
Invasive Infections Caused by Nannizziopsis spp. Molds in Immunocompromised Patients
}

\author{
Céline Nourrisson, Magali Vidal-Roux, \\ Sophie Cayot, Christine Jacomet, \\ Charlotte Bothorel, Albane Ledoux-Pilon, \\ Fanny Anthony-Moumouni, \\ Olivier Lesens, ${ }^{1}$ Philippe Poirier $^{1}$
}

We report 2 new cases of invasive infections caused by Nannizziopsis spp. molds in France. Both patients had cerebral abscesses and were immunocompromised. Both patients had recently spent time in Africa.

Tannizziopsis spp. molds have been reported in ex1 tremely rare cerebral and disseminated infections $(1,2)$, (Table). We describe 2 cases of Nannizziopsis infection diagnosed in France during the past 2 years. Both case-patients were immunocompromised and had recently returned from Africa.

\section{The Cases}

Case-patient 1 was a 63-year-old woman from France who had been treated for T-cell prolymphocytic leukemia diagnosed in December 2014. She initially received alemtuzumab, switching to bendamustine in March 2015 after tumor progression. That treatment failed, and idelalisib was started on July 11, 2015. The patient was hospitalized 2 days later for acute renal failure with mild fever. She became confused and drowsy, and cerebral computed tomography (CT) scan showed systematized subcortical hypodense areas. Lumbar puncture showed neoplastic cells in the cerebrospinal fluid (CSF) and glucose concentration within reference range. Bacteriological and fungal cultures were sterile. A large volume of ascites fluid remained, despite iterative punctures with negative bacteriological cultures. We initiated intrathecal chemotherapy with methotrexate/cytarabine/methylprednisolone. However, the patient's condition worsened, with heart failure and loss of consciousness. On July 18, we took new specimens of CSF, bronchial wash, ascites fluid, and blood cultures and sent them for bacteriological investigation. We started empiric treatment with imipenem/aminoglycosides, but the patient died on July 19 of septic shock. No autopsy was performed. Extended-spectrum $\beta$-lactamase-producing

Author affiliations: Centre Hospitalier Universitaire Clermont-Ferrand, Clermont-Ferrand, France

DOI: https://doi.org/10.3201/eid2403.170772
Escherichia coli sensitive to imipenem grew quickly in 1 pair of blood cultures. A second pair was positive 4 days later, with the presence of large septate fungal hyphae and arthroconidia. White and thin cottony mold colonies grew on Sabouraud media incubated at $35^{\circ} \mathrm{C}$ (online Technical Appendix Figure 1, https://wwwnc.cdc.gov/EID/ article/24/3/17-0772-Techapp1.pdf). We performed best model determination and phylogenetic analyses in MEGA6 (http://www.megasoftware.net). We identified N. obscura by sequencing the $18 \mathrm{~S}$-internal transcribed spacer (ITS) 1-5.8S-ITS2 region (online Technical Appendix Figure 2). The strain had low MICs for antifungals as defined by the European Committee on Antimicrobial Susceptibility Testing (http://www.eucast.org/): amphotericin B $0.06 \mu \mathrm{g} /$ $\mathrm{mL}$, itraconazole $0.25 \mu \mathrm{g} / \mathrm{mL}$, voriconazole $0.03 \mu \mathrm{g} / \mathrm{mL}$, posaconazole $0.06 \mu \mathrm{g} / \mathrm{mL}$, caspofungin $0.5 \mu \mathrm{g} / \mathrm{mL}$, and micafungin $0.015 \mu \mathrm{g} / \mathrm{mL}$. We performed mycologic investigations of CSF and ascites fluid a posteriori on frozen aliquots and conducted PCR assays targeting the ITS region on CSF sampled on July 15 and July 19 and on ascites fluid sampled on July 19. We observed positive amplifications in all samples; subsequent sequencing confirmed the presence of DNA from $N$. obscura. We investigated the origin of the patient's contamination. She had made several trips to Senegal, the latest in January 2015, during which an ulcerative inflammatory lesion developed on her left little finger. However, Grocott stain and PCR on paraffin-embedded tissue of skin biopsy were negative, and we attributed the lesion to the hematological malignancy.

Case-patient 2 was a 52-year-old woman from France living in Mali, who was hospitalized in Bamako in November 2016 for cough, fever, alteration of general state, and headache. She tested seropositive for HIV (CD4 3/ $\mu \mathrm{L}$; HIV-1 viral load 45.300 copies/mL). Chest radiograph showed bilateral pneumonia, and cerebral CT scan showed a single process on the left temporal lobe. Antiretroviral therapy was initiated with a combination of efavirenz/lamivudine/tenofovir associated with isoniazid, metronidazole, amoxicillin/clavulanate, and trimethoprime/sulfamethoxazole. Because of worsening of her neurologic status, she was repatriated to France. At hospital admission on January 12, 2017, she had a lesion on the left middle fingernail suggestive of onychomycosis, hemiparesis, and paralysis of the right side of the face

${ }^{1}$ These authors contributed equally to this article. 
Table. Characteristics of Nannizziopsis spp. infection in humans*

\begin{tabular}{|c|c|c|c|c|c|c|c|c|}
\hline $\begin{array}{l}\text { Year } \\
\text { (reference) }\end{array}$ & $\begin{array}{l}\text { Age, } \\
\text { y/sex }\end{array}$ & Country & $\begin{array}{c}\text { Underlying } \\
\text { condition or } \\
\text { context }\end{array}$ & Species & Localization & $\begin{array}{l}\text { Positive } \\
\text { samples }\end{array}$ & Treatment & Outcome \\
\hline $\begin{array}{l}2017 \text { (this } \\
\text { study) }\end{array}$ & $52 / F$ & France & $\begin{array}{l}\text { HIV, living in } \\
\text { Mali }\end{array}$ & $\begin{array}{l}\text { Nannizziopsis } \\
\text { sp. }\end{array}$ & Brain abscess & $\begin{array}{c}\text { Cerebral } \\
\text { biopsy, CSF }\end{array}$ & $\begin{array}{c}\text { AmpB for } 1 \\
\text { mo, then VCZ }\end{array}$ & $\begin{array}{c}\text { Recovery but } \\
\text { neurologic } \\
\text { sequela after } 2 \\
\text { mo }\end{array}$ \\
\hline $\begin{array}{l}2015 \text { (this } \\
\text { study) }\end{array}$ & $63 / F$ & France & $\begin{array}{l}\text { Leukemia, } \\
\text { recent travel } \\
\text { to Senegal }\end{array}$ & N. obscura & Brain abscess & $\begin{array}{c}\text { Blood } \\
\text { culture, CSF, } \\
\text { ascites fluid }\end{array}$ & $\begin{array}{l}\text { Not treated } \\
\text { (death before } \\
\text { diagnosis) }\end{array}$ & $\begin{array}{c}\text { Death before } \\
\text { diagnosis }\end{array}$ \\
\hline $2005(2)$ & $38 / \mathrm{M}$ & Germany & $\begin{array}{c}\text { HIV, travel to } \\
\text { Nigeria }\end{array}$ & N. obscura & Brain abscess & $\begin{array}{c}\text { Needle } \\
\text { aspiration of } \\
\text { brain lesion }\end{array}$ & VCZ & $\begin{array}{c}\text { Recovery } \\
\text { without } \\
\text { sequelae after } \\
4 \text { mo } \\
\end{array}$ \\
\hline $2005(5)$ & $40 / \mathrm{M}$ & $\begin{array}{l}\text { United } \\
\text { States }\end{array}$ & HIV & N. infrequens & Lung & $\begin{array}{l}\text { Bronchial } \\
\text { washing }\end{array}$ & $\begin{array}{c}\text { Not treated, } \\
\text { considered as } \\
\text { a contaminant }\end{array}$ & $\begin{array}{l}\text { Recovery after } \\
\text { treatment of } \\
\text { CMV infection }\end{array}$ \\
\hline $2000(3,4)$ & $32 / \mathrm{M}$ & $\begin{array}{l}\text { United } \\
\text { States }\end{array}$ & $\begin{array}{l}\text { Travel to } \\
\text { Nigeria }\end{array}$ & N. hominis & $\begin{array}{l}\text { Lymph nodes, } \\
\text { heart, lungs, } \\
\text { spleen, kidneys }\end{array}$ & $\begin{array}{l}3 \text { lymph } \\
\text { nodes }\end{array}$ & ITRA for $2 y$ & NA \\
\hline $1994(3)$ & $\mathrm{NA} / \mathrm{M}$ & $\begin{array}{l}\text { United } \\
\text { States }\end{array}$ & HIV & N. hominis & $\begin{array}{l}\text { Right thigh } \\
\text { mass }\end{array}$ & $\begin{array}{l}\text { Deep muscle } \\
\text { mass on the } \\
\text { right thigh, } \\
\text { right groin, } \\
\text { buttock, and } \\
\text { lung }\end{array}$ & ITRA & $\begin{array}{c}\text { Death after } 8 \\
\text { mo }\end{array}$ \\
\hline $1982(1)$ & $24 / \mathrm{M}$ & $\begin{array}{l}\text { United } \\
\text { States }\end{array}$ & $\begin{array}{c}\text { Travel to } \\
\text { Africa }\end{array}$ & N. obscura & $\begin{array}{c}\text { Abscess in right } \\
\text { ankle, } \\
\text { osteomyelitis }\end{array}$ & $\begin{array}{c}2 \text { biopsies of } \\
\text { abscess in } \\
\text { tibia }\end{array}$ & $\begin{array}{c}\text { AmpB for } 4 \\
\text { mo }\end{array}$ & $\begin{array}{c}\text { Recovery after } \\
4 \text { mo }\end{array}$ \\
\hline
\end{tabular}

associated with Broca's aphasia. A thoracic-abdominalpelvic scan revealed a nodular lesion in the right lung (Figure, panel A) and multiple partly calcified pleural lesions. Bacteriological assays, including investigation for mycobacteria on bronchoalveolar lavage (BAL) fluid, showed negative results. A Penicillium grew rapidly on mycological medium, and Pneumocystis jiroveci PCR results were slightly positive. Cranial tomodensitometry showed multiple gadolinium-enhancing nodules surrounded by edema (Figure, panel B). We initiated fluconazole and pyrimethamine/sulfadiazine and switched antiretroviral therapy to raltegravir/abacavir/lamivudine after the onset of acute renal insufficiency. Hemiplegia developed 15 days later. A new CT scan showed stable cerebral lesions but an increase in surrounding edema. We performed a lumbar puncture and started intravenous corticotherapy. CSF contained 127 leukocytes (61\% lymphocytes) and showed hypoglycorrhachia. Investigations for toxoplasmosis, cryptococcosis, histoplasmosis, tuberculosis, and CMV showed negative results, but ITS-targeting PCR results were positive on CSF. The sequence was closely related to N. obscura, but mycological cultures were sterile (online Technical Appendix Figure 2). The results of a $\beta$-D-glucan assay of serum was positive ( $983 \mathrm{pg} / \mathrm{mL}$; Fungitell, Associates of Cape Cod, Inc., http://www.acciusa. $\mathrm{com} / \mathrm{clinical} /$ fungitell/index.html) and galactomannan antigen was negative. On February 6 , we performed a cerebral biopsy. Histopathologic examination showed granuloma containing hyphae (Figure, panels C, D), and on the fourth day of incubation, white mold grew on Sabouraud media at $25^{\circ} \mathrm{C}$ and $35^{\circ} \mathrm{C}$ (online Technical Appendix Figure 1). The phylogenetic analyses of the 18S-ITS1-5.8S-ITS2 region confirmed that the fungus belonged to Nannizziopsis spp. Although the $18 \mathrm{~S}$ region was closely related to $N$. obscura, the ITS1 region had a large insertion, suggesting the strain does not belong to the described Nannizziopsis species (online Technical Appendix Figure 2). Strain MICs as defined by the European Committee on Antimicrobial Susceptibility Testing were amphotericin B 0.25 $\mu \mathrm{g} / \mathrm{mL}$, itraconazole $0.03 \mu \mathrm{g} / \mathrm{mL}$, voriconazole $0.125 \mu \mathrm{g} /$ $\mathrm{mL}$, posaconazole $0.25 \mu \mathrm{g} / \mathrm{mL}$, caspofungin $0.25 \mu \mathrm{g} / \mathrm{mL}$, and micafungin $\leq 0.008 \mu \mathrm{g} / \mathrm{mL}$. We initiated liposomal amphotericin B $(5 \mathrm{mg} / \mathrm{kg})$. On July 16 , the patient became drowsy with a bilateral pyramidal syndrome and moderate reactive mydriasis. Cranial CT scan showed an increase in the abscesses and edema with brain displacement. We performed a craniotomy. One month after diagnosis, the patient's general status had improved, with regression of the lung lesions and cerebral abscesses; her $\mathrm{CD}_{4}$ cell count was $50 / \mu \mathrm{L}$ and HIV-1 load $<40$ copies $/ \mathrm{mL}$. We switched her antifungal treatment to voriconazole.

\section{Conclusions}

The molds of the $N$. vriesii complex (Chrysosporium-like anamorph, CANV) are members of the Nannizziopsis genus (Onygenales, Eurotiomycetidae, Eurotiomycetes, Ascomycota). 
CANV includes the keratinophilic species, which causes skin and fatal disseminated infections in reptiles $(3,4)$. There is no documented evidence of zoophilic species involvement in human infections, but 3 other CANV species have been recovered from human samples (Table). Of the 5 previous cases of Nannizziopsis infections, 3 involved HIV patients. One of our patients was seropositive for HIV and the other had T-cell prolymphocytic leukemia, which suggests that lymphopenia could be a key risk factor. All patients with reported N. obscura infection had recently traveled in Africa. Results for case-patient 1 showed that the fungus grows in blood cultures and thus has high potential for dissemination. Case-patient 2 had pulmonary lesions, but BAL cultures were rapidly invaded by a Penicillium fungus. Although we could not detect Nannizziopsis in BAL, the lesion evolved favorably after antifungal therapy. Because Nannizziopsis spp. are keratinophilic molds, we looked for cutaneous lesions. Both case-patients had recently developed cutaneous or nail lesions during their time in Africa, but we did not detect Nannizziopsis from these lesions. These molds have not been isolated in our laboratory in other kinds of samples (clinical or environmental).
CSF cultures from both our case-patients and ascites cultures from case-patient 1 were negative, but panfungal PCR successfully detected molds (6). Data on biomarkers are scarce. $N$. infrequens cross-reacts with the Histoplasma AccuProbe test and N. hominis with the Blastomyces AccuProbe test (Hologic, San Diego, CA, USA) (5). In case-patient $2, \beta$-D-glucan was positive in CSF and serum but galactomannan antigen was not. $N$. obscura seems to be sensitive to most antifungal agents (2).

These observations show how difficult this infection is to detect, which could explain why so few cases of human infections have been reported. However, the diagnosis of these 2 cases since 2015 suggests that the prevalence of Nannizziopsis infections may be underestimated.

\section{Acknowledgments}

The authors thank all the members of the Centre National de Référence des Mycoses et Antifongiques (CNRMA, Institut Pasteur de Paris, France) for their invaluable help in the antifungal susceptibility testing.
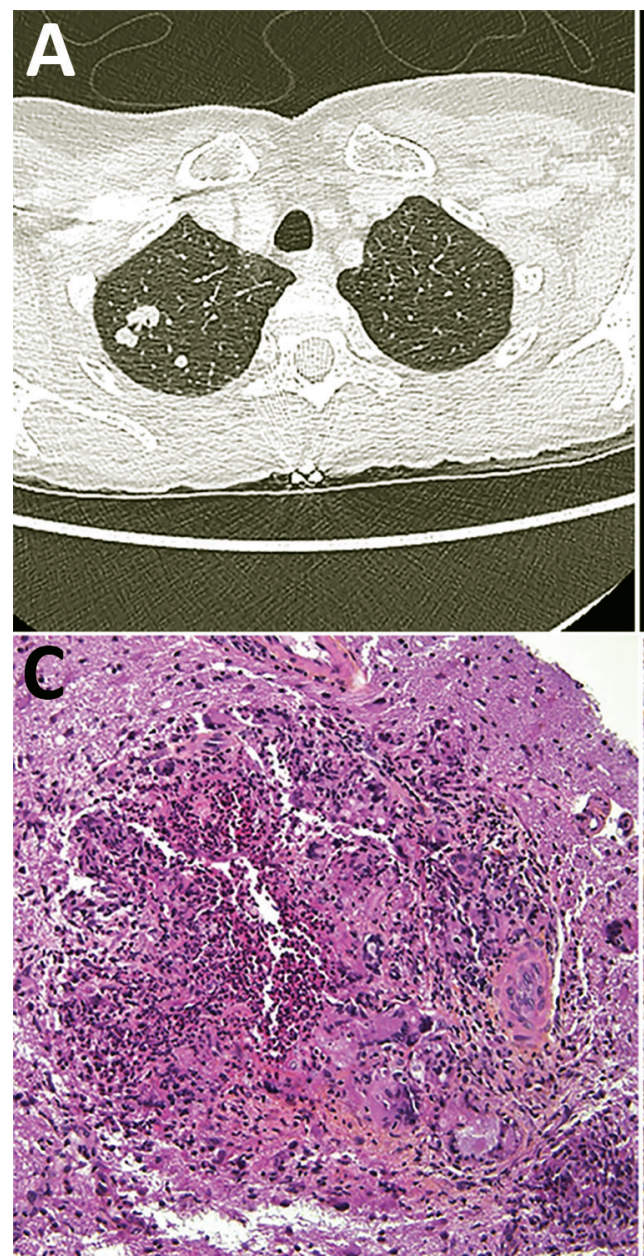
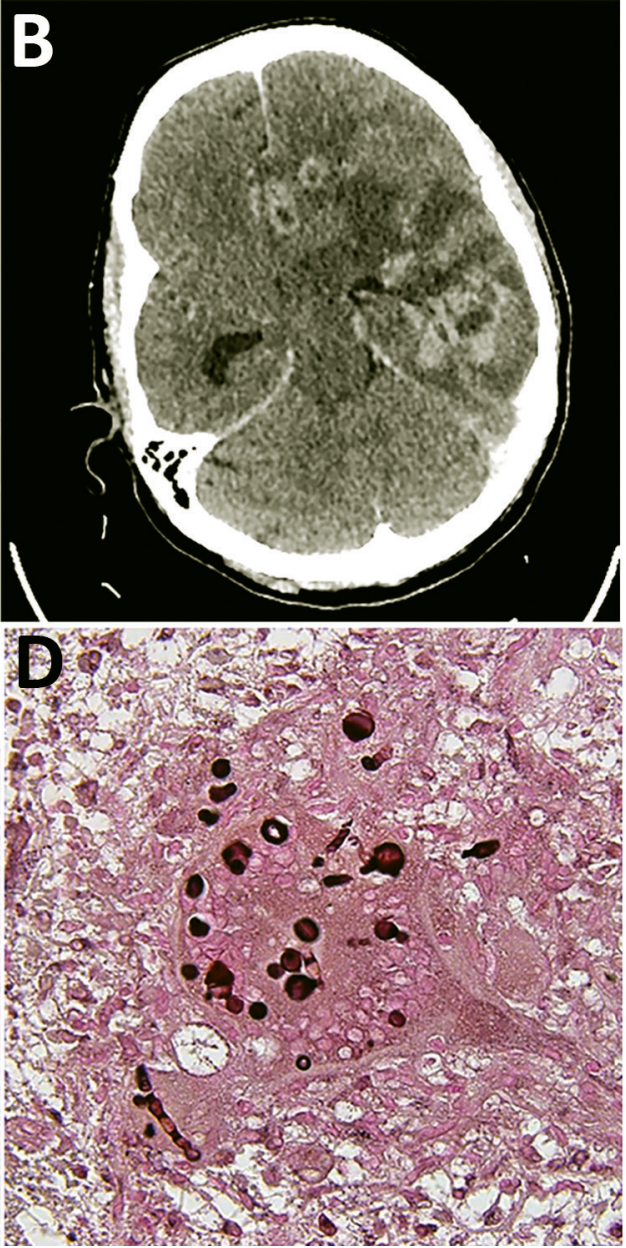

Figure. Diagnostic testing of a 52-year-old woman from France living in Mali who had Nannizziopsis spp. fungal infection. A) Thoracic-abdominalpelvic scan shows pseudo-nodular lesions in the apex of the right lung, of which one is excavated. B) Cerebral computed tomography scan shows contrast enhancement on several hemispheric nodules on the left and in frontal, parietal, and temporal regions, responsible for large surrounding edema and compression of the left lateral ventricle. The median line is deviated to the right with a subfalcorial herniation. C) Hematoxylin-eosin-saffron stain of brain biopsy containing mononuclear inflammatory infiltrates; giant cell granulomas; histiocytes, sometimes with an epithelioid appearance; and neutrophils (original magnification $\times 200$ ). D) Grocott stain showing thick bulbous mycelial filaments in the cytoplasm of certain giant cells/histiocytes (original magnification $\times 600$ ). Round shapes correspond to crosssections of bulbous territories. 


\section{About the Author}

Dr. Nourrisson is a medical mycologist and parasitologist at the university hospital of Clermont-Ferrand, France. Her research interests include medical fungi epidemiology and digestive protozoa.

\section{References}

1. Stillwell WT, Rubin BD, Axelrod JL. Chrysosporium, a new causative agent in osteomyelitis. A case report. Clin Orthop Relat Res. 1984; (184):190-2.

2. Steininger C, van Lunzen J, Tintelnot K, Sobottka I, Rohde H, Horstkotte MA, et al. Mycotic brain abscess caused by opportunistic reptile pathogen. Emerg Infect Dis. 2005;11:349-50. http://dx.doi.org/10.3201/eid1102.040915

3. Sigler L, Hambleton S, Paré JA. Molecular characterization of reptile pathogens currently known as members of the Chrysosporium anamorph of Nannizziopsis vriesii complex and relationship with some human-associated isolates. J Clin Microbiol. 2013;51:3338-57. http://dx.doi.org/10.1128/JCM.01465-13
4. Stchigel AM, Sutton DA, Cano-Lira JF, Cabañes FJ, Abarca L, Tintelnot K, et al. Phylogeny of chrysosporia infecting reptiles: proposal of the new family Nannizziopsiaceae and five new species. Persoonia. 2013;31:86-100. http://dx.doi.org/ $10.3767 / 003158513 \times 669698$

5. Brandt ME, Gaunt D, Iqbal N, McClinton S, Hambleton S, Sigler L. False-positive Histoplasma capsulatum Gen-Probe chemiluminescent test result caused by a Chrysosporium species. J Clin Microbiol. 2005;43:1456-8. http://dx.doi.org/10.1128/ JCM.43.3.1456-1458.2005

6. Ihrmark K, Bödeker ITM, Cruz-Martinez K, Friberg H, Kubartova A, Schenck J, et al. New primers to amplify the fungal ITS2 region - evaluation by 454-sequencing of artificial and natural communities. FEMS Microbiol Ecol. 2012;82:666-77. http://dx.doi.org/10.1111/j.1574-6941.2012.01437.x

Address for correspondence: Philippe Poirier, Laboratoire de Parasitologie-Mycologie, Centre de Biologie, CHU Gabriel Montpied, 58 rue Montalembert, 63000 Clermont-Ferrand, France; email: ppoirier@chu-clermontferrand.fr

\section{March 2014: Mycobacterial Infections}

- Invasive Fungal Infections after Natural Disasters

- Monitoring Water Sources for Environmental Reservoirs of Toxigenic Vibrio cholerae O1, Haiti

- High Level Relatedness among Mycobacterium abscessus subsp. massiliense Strains from Widely Separated Outbreaks
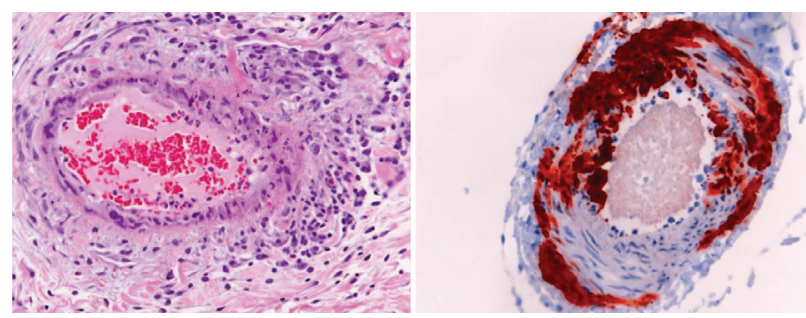

- Hendra Virus Vaccine, a One Health Approach to Protecting Horse, Human, and Environmental Health

- Possible Role of Songbirds and Parakeets in Transmission of Influenza A(H7N9) Virus to Humans

- Hantavirus Infections among Overnight Visitors to Yosemite National Park, California, USA, 2012

- Neisseria meningitidis Serogroup W, Burkina Faso, 2012

- Use of Drug-Susceptibility Testing for Management of Drug-Resistant Tuberculosis, Thailand, 2004-2008

- Comparison of Imported Plasmodium ovale curtisi and P. ovale wallikeri Infections among Patients in Spain, 2005-2011

- Postmortem Diagnosis of Invasive Meningococcal Disease
- Coxiella burnetii Seroprevalence and Risk for Humans on Dairy Cattle Farms, the Netherlands, 2010-2011

- Minimal Diversity of Drug-Resistant

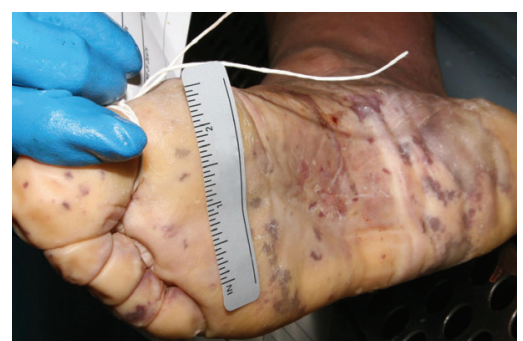
Mycobacterium tuberculosis Strains, South Africa

- Drought and Epidemic Typhus, Central Mexico, 1655-1918

- Surveillance for Antimicrobial Drug Resistance in Under-Resourced Countries

- Nontoxigenic tox-Bearing Corynebacterium ulcerans Infection among Game Animals, Germany

- Urban Epidemic of Dengue Virus Serotype 3 Infection, Senegal, 2009

- Role of Placental Infection in Miscarriage

- IgG against Dengue Virus in Healthy Blood Donors, Zanzibar, Tanzania

- Mimivirus Circulation among Wild and Domestic Mammals, Amazon Region, Brazil

- Infective Endocarditis in Northeastern Thailand

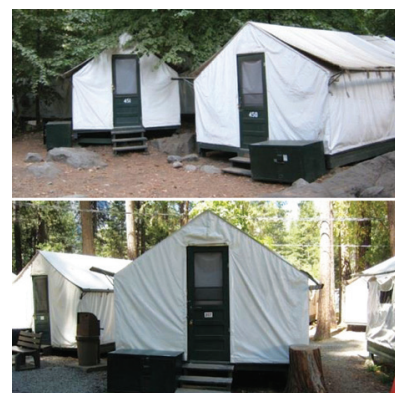

